M.I. Baranov

\title{
AN ANTOLOGY OF THE DISTINGUISHED ACHIEVEMENTS IN SCIENCE AND TECHNIQUE. PART 30: PORTRAIT OF THE KHARKOV MATHEMATICIAN, MECHANICAL ENGINEER AND CYBERNETICIST VLADIMIR LOGVINOVICH RVACHEV
}

Purpose. Description of basic scientific achievements, features of personality and way of life of the known Kharkov mathematician, mechanical engineer and cyberneticist, academician of NAS of Ukraine Rvachev V.L .in the short form is presented. Methodology. Existent scientific approaches for treatment and systematization of mathematical knowledges, modern achievements in area of methods of direct solution of linear (nonlinear) boundary problems of mechanics and mathematical physics with the scope terms of different types for the physical bodies of difficult geometrical form. Methods of historical method at research of development in society of analytical geometry, applied mathematics, classical mechanics and mathematical physics. Results. Short information is resulted about the basic creative and vital stages, and also fundamental scientific achievements of the indicated scientist-mathematician the scientific legacy of which entered in the treasure-house of world mathematical science. Are some personal qualities of this prominent soviet Ukrainian mathematician of the 20-th century, forming scientific school on the mathematical method of $R$-functions and leaving about itself kind memory for thankful students and descendants. Originality. First taught in 1970-th at the known mathematician of contemporaneity of Rvachev V.L. to bases of the applied mathematics and theory of $R$-functions by a scientist-electrophysicist from the Kharkov polytechnic institute presented for the wide circle of readers a short scientifically-historical essay about this large scientist-teacher, being based on his scientific labours, published biobibliographic materials and flashbacks of his devoted studentsfollowers about him. Practical value. Scientific popularization of the special physical and mathematical knowledges and distinguished scientific achievements of the known Kharkov scientist-mathematician Rvachev V.L. in area of the applied mathematics, classical mechanics of continuous media, mathematical physics and technical cybernetics. References 43, figures 13.

Key words: history, mathematics, mechanics, cybernetics, Kharkov region, distinguished scientific achievements.

Приведен краткий научно-исторический очерк об известном ученом-математике Харьковщины - академике АН УССР (НАН Украины) Рвачеве В.Л. и о его выдающемся вкладе в мировую математическую науку. Библ. 43, рис. 13.

Ключевые слова: история, математика, механика, кибернетика, Харьковская область, выдающиеся научные достижения.

90th anniversary of Vladimir Logvinovich Rvacheva famous Ukrainian mathematician mechanical engineer and cybernetics dedicated.

Introduction. Papers [1, 2] have previously been described by the author of a number of portraits of the outstanding mathematicians of Kharkiv - Ukrainian Soviet and Russian academics Pogorelov A.V., Marchenko V.A and Sadovnichy V.A., as well as a correspondent member of the Ukrainian Academy of Sciences Akhiezer N.I., which became in the second half of the 20th and early 21 st century, the personification of intellectual image of Kharkiv, and close to many of us Slobozhanshina region. The continuation of this academic «mathematical» a number of prominent Russian scientists, mathematicians for such leading scientific and educational centers of Ukraine as Kharkiv, certainly is and our illustrious compatriot - Doctor of Physical and Mathematical Sciences, Prof., Academician of the Ukrainian Academy of Sciences (NASU) Vladimir Logvinovich Rvachev [3].

His basic mature creative, scientific and educational life he spent in the «walls» of the Institute of Mechanical Engineering Problems (IPMach) named after Academician NASU A.N. Podgorny and Kharkiv Polytechnic Institute (KhPI). Author in 1976 while studying at postgraduate KhPI was fortunate to attend a course of lectures on applied mathematics and foundations of the so-called R-functions performed by this well-known mathematician and an excellent teacher. Remembering with a share of nostalgia that «golden» period of scientific research, the requirements of the many manifestations of extremism in their youth, creative hobbies and education, I can say that the empty seats in the classroom in the classroom scientist-maitre V.L. Rvachev usually not. These sessions aim to proactively attend professional development of young professionals and other leading universities of Kharkiv. It is time to his many disciples and who knew this remarkable Kharkiv mathematics experts from other fields of scientific activities to acquaint the general reader with this significant for the domestic and international public research and the human figure. So try in the form of short scientific and historical essay on the basis of scientific papers by Rvachev V.L. known literary sources, materials Museum KhPI, photographs from the family archive of our illustrious scientist and information from the Internet to «draw» a portrait of this extraordinary personality with a description of its major outstanding scientific results in the field of applied mathematics, mechanical engineer and mathematical physics. 
1. The main stages of the life and career of the Kharkiv academic mathematician. Born Rvachev V.L. (Fig. 1) October 21, 1926 in Chigirin (Cherkasy region) in a family of teachers [3, 4]. After graduating from high school in the difficult years of the Second World War, he worked as an apprentice turner at the «Tashselmash» (Tashkent). In 1944 he was called to serve in the Navy of the USSR. After demobilization in 1947 he entered the Physics and Mathematics of Lviv University named after Franko. In 1952 Rvachev V.L. graduated from a higher educational institution of the USSR (Fig. 2).

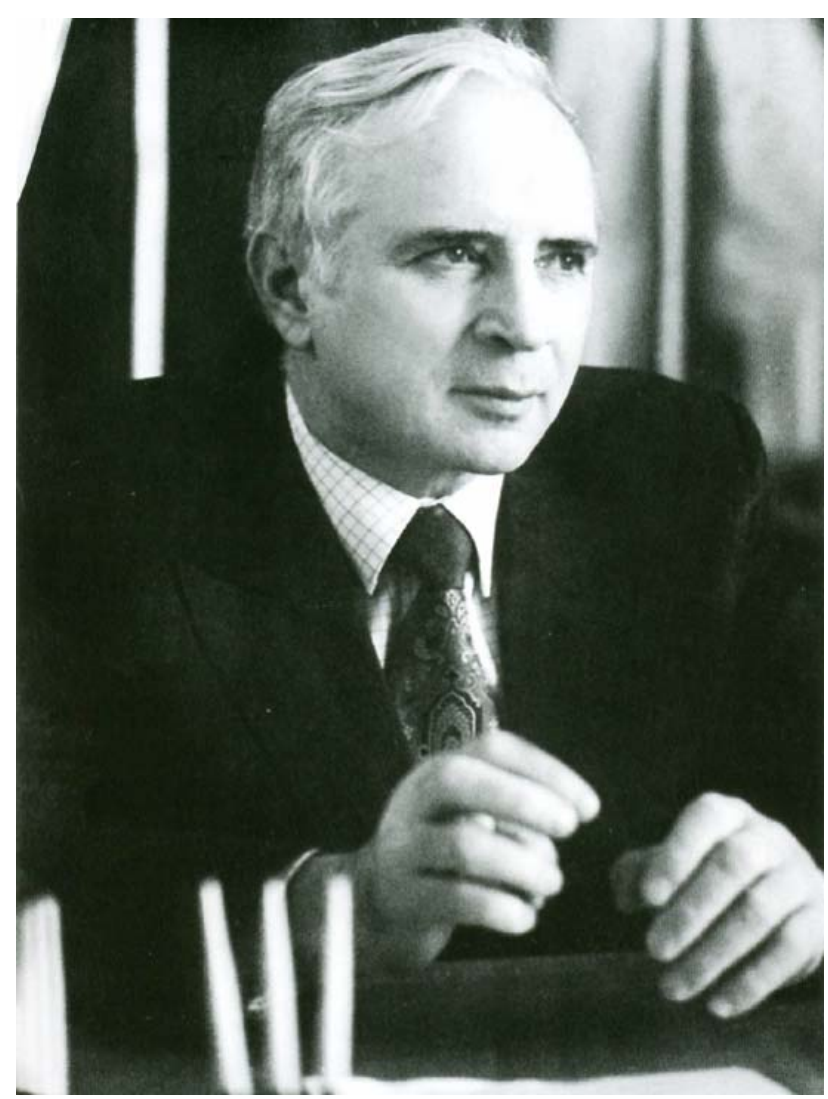

Fig. 1. Outstanding Soviet Ukrainian mathematics, mechanical engineer and cybernetics, Doctor of Physical and Mathematical Sciences, Prof., Academician of the Ukrainian Academy of Sciences (NASU), laureate of the State Prize of the USSR in the field of Science and Technology, Honored Worker of Science and Technology, an honorary doctor of NTU «KhPI» and other universities Vladimir Logvinovich Rvachev (1926-2005) [4]

By the way, in the 4th year of the above university, he was a scholar of Stalin [4]. After graduating from the University of Lviv named after Franko and being already married to his classmate Irina Konstantinova Semiray full of creative plans Rvachev V.L. again in the ranks of the Soviet Navy, working as a lieutenant of the Soviet Navy senior lecturer at the Naval Academy (Pushkino, Leningrad region) [3, 4]. Despite these harsh circumstances of life, in 1955, he successfully defended his thesis on «The calculation of the infinite beam lying on an elastic foundation» (supervisor Prof. M.J. Leonov) and becomes Candidate of Physical and Mathematical Sciences $[3,4]$. For family reasons (because of the urgent need to change the climate for the wife) Rvachev V.L. and Rvacheva I.K. in 1955 moved to the warm Sea of Azov, and both are teachers of the department of higher mathematics in Berdyansk Pedagogical Institute [3, 4].

It is believed that in the initial period of the life and scientific formation of Rvachev V.L. Berdyansk is a period (1955-1963), his life and scientific activity proved to be a most vivid and fruitful [5-10]. In 1960, he successfully defended at the Institute of Mechanics of the USSR Academy of Sciences doctoral thesis on «The spatial contact problem of elasticity theory and some of its applications» $[3,4]$. It is believed that in the final moment of preparation for the defense of the scientific work on mechanics, he «went to the main result of his future mathematical discoveries» [4]. Opening concerned special R-functions («Rvachev functions»), solves the problem of taking into account a complex geometric configuration (information) for any technical object during analysis. Basic scientific work at it for a fundamentally new direction in mathematics - the theory R-functions became his short article [11].

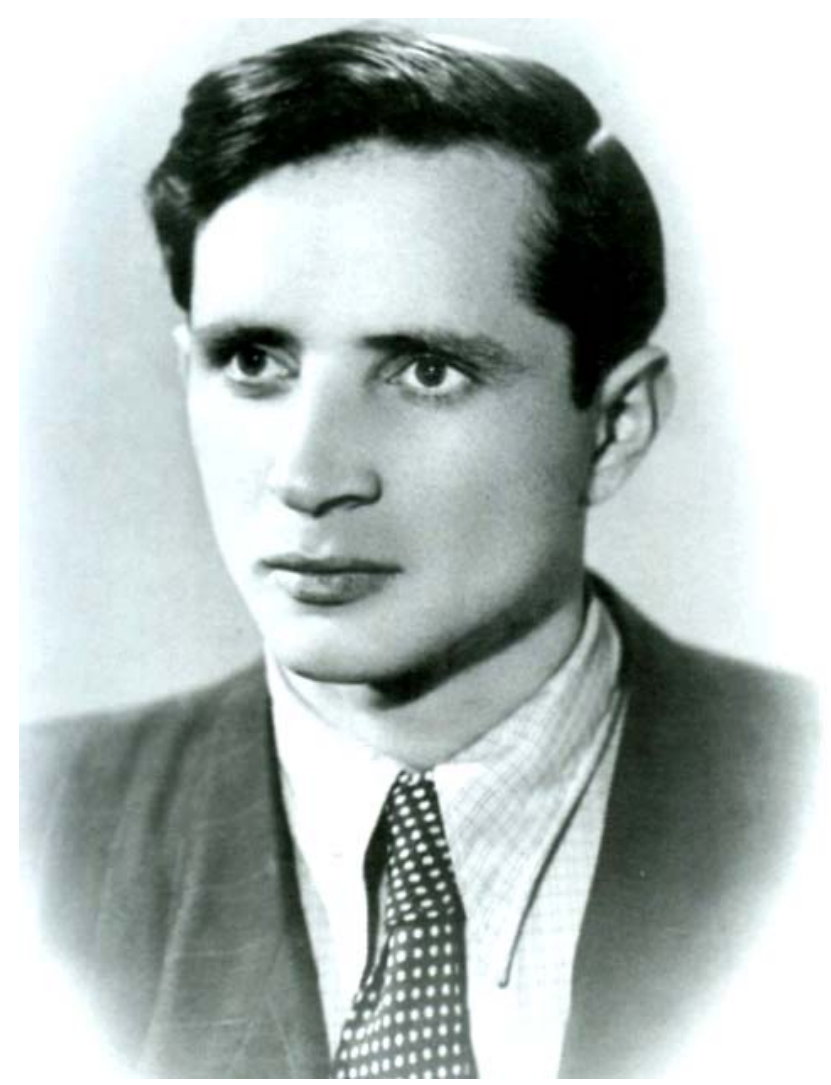

Fig. 2. Purposeful mathematician Rvachev V.L. after the Physics and Mathematics Faculty of the Lviv University named after Franko (1952, Lviv) [4]

In 1963, Doctor of Physical and Mathematical Sciences, Prof. Rvachev V.L. was invited to work at the Kharkiv Institute of Mining Engineering, Automation and Computer Engineering (in the near future, the Kharkiv Institute of Radio Electronics - KhIRE) to head the Department of Computational Mathematics [3, 4]. Beginning of Kharkiv period (1963-2005) work for Rvachev V.L. (Fig. 3) coincided with a period of rapid development in the Soviet Union cybernetics and 
computer science. In this regard, Rvachev V.L. boundary value problems of mechanics began to consider since the common position of the theory of science. That is why his attention was drawn to the problem of geometrical information specific to a broad class of optimization problems and mathematical physics solved with the help of computers - computers [3]. It is believed that the mathematical theory R-functions proposed Rvachev V.L., originated at the crossroads of the classical methods of applied mathematics, cybernetics and methods of mathematical logic $[3,4]$.

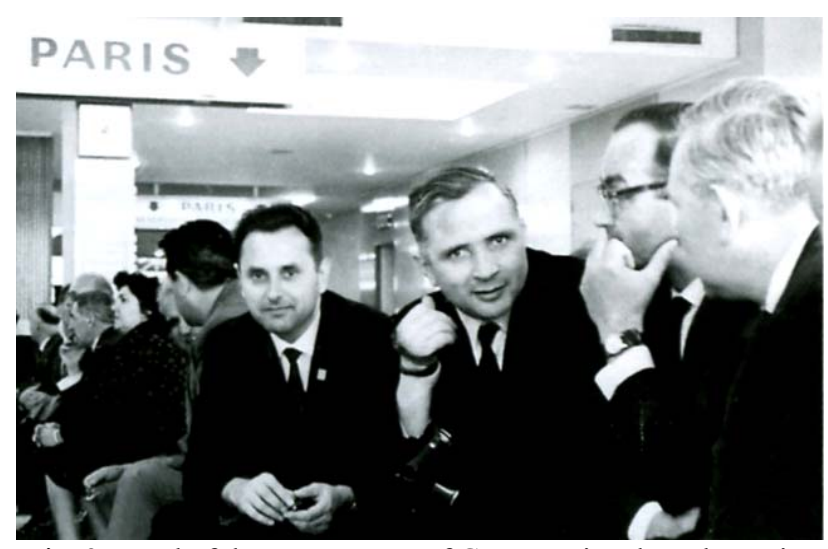

Fig. 3. Head of the Department of Computational Mathematics KhIRE, Doctor of Physical and Mathematical Sciences, Prof. Rvachev V.L. (third from right) before flying out of the airport of Paris home after successful participation in the International Conference on Computational Mathematics and Cybernetics (1966) [4]

Heading 1967 Department of Applied Mathematics and Computational Methods in IPMach of the Ukrainian Academy of Sciences, Doctor of Physical and Mathematical Sciences, Prof. Rvachev V.L. (Fig. 4), together with colleagues in the period $1960-1980$ is developing the mathematical apparatus of the theory of Rfunctions [12-19].

Developing the theory R- functions Rvachev V.L. drew particular attention to the constructive means of its implementation. It is the lack of such structural funds so long restrained use of classical variational methods for constructing explicitly coordinate functions exactly satisfy the given boundary conditions for the areas of complex geometrical shape [3, 4]. Rvachev V.L. together with their students through constructive theory of Rfunctions of functions we have developed a common approach to the problem of constructing coordinate sequences known for the main variation and projection methods [20]. At the same time it was the decision of problems of mechanics, electrodynamics, thermal physics and mathematical physics with boundary conditions of various types for almost any form fields [20]. Mathematical R-functions method in the future was a universally recognized abbreviation $R F M$ [4].

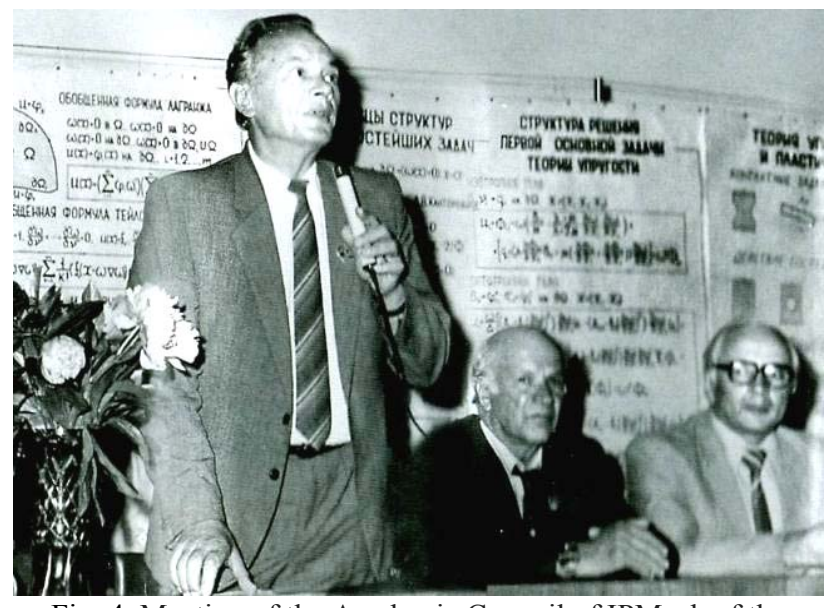

Fig. 4. Meeting of the Academic Council of IPMach of the Ukrainian Academy of Sciences, chaired by its director, correspondent member of the Ukrainian Academy of Sciences Anatoly N. Podgorny, discuss the achievements of the USSR Academician V.L. Rvachev (far right) and his students in the development and practical application of a mathematical apparatus of R-functions in mechanics

cybernetics, thermal physics, electrodynamics, radio physics and other technical applications (1985, Kharkiv) [4]

In 1969, Doctor of Physical and Mathematical Sciences, Prof. Rvachev V.L. was invited by the rector of KhPI Prof. Semko M.F. to head the department on the theoretical and mathematical physics at the permanent place of his work in IPMach of the Ukrainian Academy of Sciences [4]. During this time period, the search for effective organization of the numerical solution of boundary value problems of mathematical physics led Rvachev V.L. to understand the need to create a new programming technology [3]. In 1970, under his supervision in the department of applied mathematics and computational methods IPMach of the Ukrainian Academy of Sciences started work on the creation of the first version of automated programming systems family «Field» $[3,4]$. In the future, by these institutions in the system «field» become instrumental base for numerical experiments and solve many practical problems, freeing mathematicians and engineers in various fields from the programming process [3].

1972, Doctor of Physical and Mathematical Sciences, Prof. Rvachev V.L. was elected as Corresponding Member of the Ukrainian Academy of Sciences, and in 1978 - full member of the Ukrainian Academy of Sciences [3, 4]. In 1980, for the development, creation and implementation of the national economy of the theory functions R-functions group of authors of employees IPMach of the Ukrainian Academy of Sciences as part Rvachev V.L. (head of investigations) and his disciples Stoyan Y.G., Protsenko V.S., Manko G.P., Slesarenko A.P., Shejko T.I. and Sinekop N.S. was awarded the State Prize of Ukraine in the field of science and technology $[3,4]$. We point out that the results of studies by Rvachev V.L. On the supply side, and he adjusted his students to use in practice, the mathematical method R-functions (RFM) for the period of his active work are reflected in more than 350 [3]. The author also 
because of the limited scope of this essay is only referred to their score. These must include at least another two monographs by the Academician of the NASU V.L. Rvachev defining certain stages and development perspectives in science «Rvachev functions». It is published in Ukraine following books: in 1967 «Geometric applications of algebra of logic» [21] and in 1974, «Methods of the algebra of logic in mathematical physics» [22].

In my opinion, one of the main factors that led it our hero scientist in mathematical discovery of special Rfunctions features is the fact that this man had an encyclopedic knowledge. He was the highest expert not only in terms of pure mathematics, and engineering cybernetics (the science of the laws governing the management processes and information transfer machines [23]), as well as classical mechanics, mathematical physics and mathematical logic (Boolean algebra, based on logical operations Similar actions on sets [23]). It is a synthesis of these unique abilities and knowledge, focusing it, and brought Rvachev V.L. to consider opening. Needs practice in solving complex scientific and technical problems in these areas of knowledge and skill of Rvachev V.L. in a complex cover such problems, and brought him to the scientific insight - creation theory of R-functions.

October 21, 1986 the academic community of Kharkov and the whole of our country celebrated the 60th anniversary of the outstanding scientist of our time, academician of the USSR Vladimir Logvinovich Rvachev, held at his place of work in the long at his native IPMach of the Ukrainian Academy of Sciences (Fig. 5).

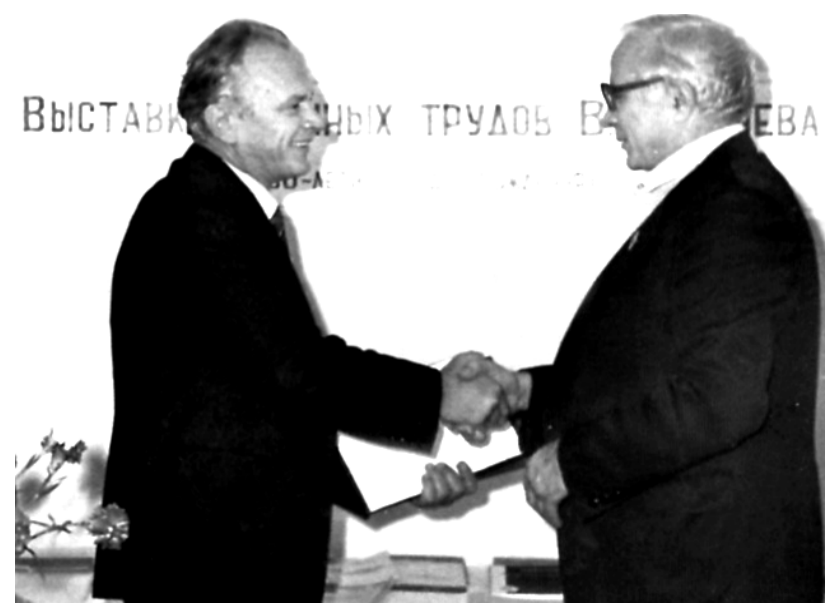

Fig. 5. Director of IPMach of the Ukrainian Academy of Sciences, Corresponding Member of the Ukrainian Academy of Sciences A.N. Podgorny (left) warmly congratulates the 60th anniversary of his dear colleague, jubilee - Ukrainian Academy of Sciences Academician V.L. Rvachev (right) (1986,IPMach of the Ukrainian Academy of Sciences, Kharkiv) [4]

Subsequent decades of fruitful scientific and pedagogical activity in IPMach of the Ukrainian Academy of Sciences (NASU) and NTU «KhPI» (since 1971 as a professor of the department of the above
University, called since 1981 the Department of Applied Mathematics, part-time) our domestic scientist Maitre Rvachev V.L. dedicated individual topical areas of application in the field of mechanics (contact problems of elasticity theory and nonlinear problems of the theory of plates of complex shape), thermal physics, magnetohydrodynamics, physics, cybernetics (automation software tasks in solving boundary value problems) and mathematics (problems in the theory approximation and atomic functions), to develop him and his numerous students on the basis of the data created by the worldrenowned creator of the mathematical theory of Rfunctions [24-38].

Academician of the National Academy of Sciences of Ukraine V.L. Rvachev (Fig. 6) at the beginning of the 21 st century he has continued the best of their moral standing and physical strength to work in his areas of educational and scientific spheres as an academic consultant IPMach NASU, «his» chair of applied mathematics at the NTU «KhPI», KhIRE and aerospace University «Kharkiv Aviation Institute» until his death, the ensuing 26 April 2005 [4, 39-42].

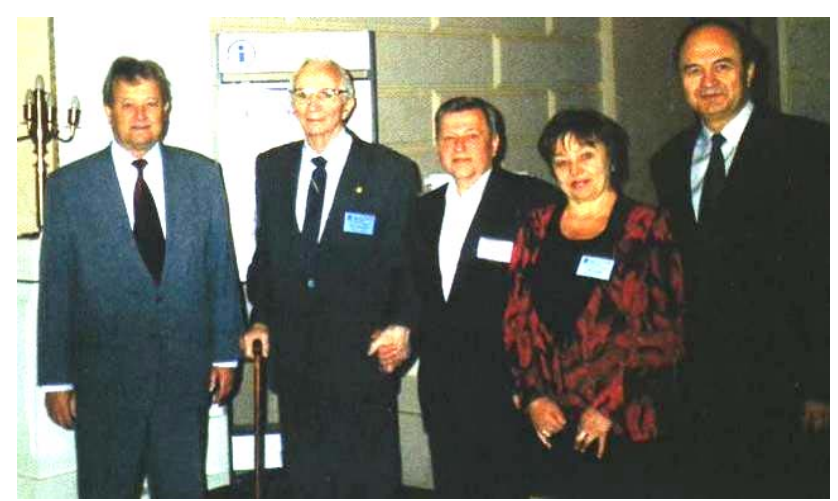

Fig. 6. The members of the organizing committee of the international conference on nonlinear dynamics «Nonlinear Dynamics» (from left to right: Prof. Tovazhnyansky L.L., academician of the NAS Rvachev V.L.,Prof. Morachkovsky O.K., Prof. Kurpa L.V., Prof. Kravets V.A., 2004, NTU «KhPI», Kharkiv) [4]

October 23, 2006 in NTU «KPI» in honor of the outstanding scientist of the XX century in the field of mathematics and mechanics, the author of scientific ideas for the theory of $\boldsymbol{R}$-functions, academician of the NASU Rvachev V.L. it was discovered a marble plaque (Fig. 7).

2. Main scientific achievements of the Kharkiv academic mathematician. Scientifically known Prof. V.L. Rvachev brought the original results of his work on a solution based on a new mathematical approach of boundary value problems in classical mechanics, mathematical physics, thermal physics, electrodynamics, radio physics and magnetohydrodynamics. We will try to lower it on the basis of a number of scientific papers [3, 5-22, 24-38] to formulate the basic fundamental scientific results obtained by famous mathematician, academician of the Ukrainian Academy of Sciences (NASU) V.L. Rvachev in these areas of physical and mathematical knowledge: 
- Formulated at the present mathematical level of knowledge of the centuries-old scientific problem that goes back to the founder of analytical geometry - the great French mathematician and physicist René Descartes (1596-1650) And consisting of the construction of the equation of a geometric object of any shape he was initially given a graphic outline or drawing $\left(1960^{\text {th }}\right.$ years $)$;

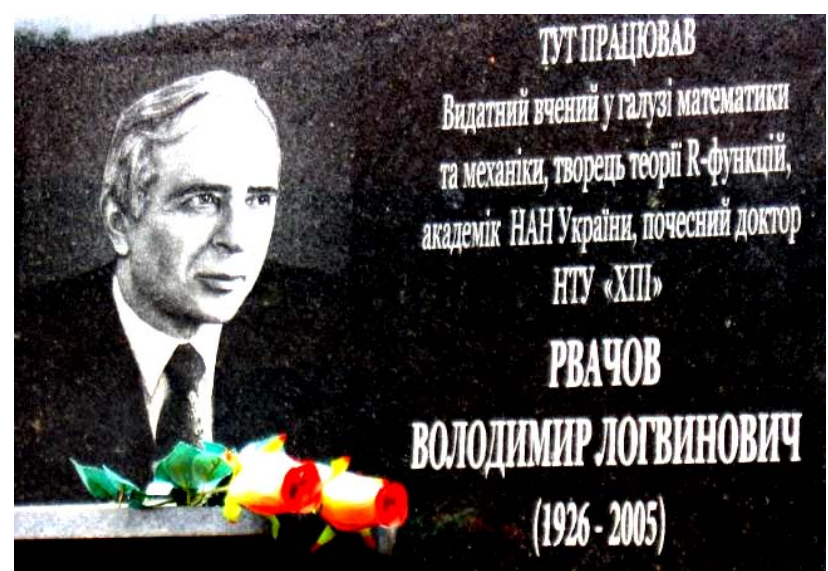

Fig. 7. General view of the marble memorial plaque in honor of outstanding Soviet Ukrainian Mathematics and Cybernetics,

Academician of NAS of Ukraine, honorary doctor of NTU «KhPI» Vladimir Logvinovich Rvachev (1926-2005), Opened in NTU «KPI» in 2006 and mounted on a brick wall of Mathematical Building of the University

- Developed in relation to the solution of boundary value problems of classical mechanics, thermal physics, mathematical physics, electrodynamics, radio physics and magnetohydrodynamics new mathematical method for constructing complete systems of basis (coordinate) functions for geometric objects of arbitrary configuration with boundary conditions of various types and an arbitrary functional form of the recording, use the original special R-function (Rvachev functions) (1960 ${ }^{\text {th }}$ years);

- Developed a framework of a new mathematical theory of R-functions with its numerous technical applications, one of the main results of which is the inverse problem of analytical geometry, which consists in establishing a mathematical equation for a given geometric object of arbitrary shape, which describes its geometry and the coordinates of its external borders for different areas in two- and three-dimensional Euclidean space $\left(1960^{\text {th }}\right.$ years $)$;

- Submitted the required equation for the inverse problem of analytic geometry and the coordinates of external borders (coordinate functions of the boundary conditions for the boundary value problems in technical applications) for geometric objects of complex shapes in a single analytic expression that contains elementary functions $\left(1970^{\text {th }}\right.$ years $)$;

- Detail developed and brought to practical application in solving various boundary value problems of classical mechanics, thermal physics, mathematical physics, electrodynamics, the theory of radio physics and magnetohydrodynamics R-functions is the opinion of authoritative scholars one of the great scientific discoveries in the field of applied mathematics of the second half 20 century (1970 ${ }^{\text {th }}$ years) [40-42];

- On the basis of the constructive universal theory Rfunction creates a new programming technology, implemented under his supervision in the department of applied mathematics and computational methods IPMach of the Ukrainian Academy of Sciences in relation to direct methods for solving boundary value problems in mechanics and mathematical physics described by partial differential equations, in the form automated programming systems family «Field» $\left(1970^{\text {th }}-1980^{\text {th }}\right.$ years);

- Solved large complex application of linear and nonlinear two-and three-dimensional boundary-value problems in the theory of elastic plates, rods, hollow cylinders and other metal complex form, transient heat conduction of solid bodies of finite size, and the theory of electromagnetism in relation to radio and antenna systems with MHD generators R-method involving mathematical functions $(R F M)\left(1970^{\text {th }}-2000^{\text {th }}\right.$ years $)$;

- With the aid of his theory of generalized R-functions and constructively implemented in functional spaces are widely used in practice the formula of Taylor-LagrangeHermite that will open a new class of finite infinitely often differentiable functions (atomic functions) that are of great practical importance for the further development approximation theory, methods of digital processing of electrical signals and methods for solving diverse boundary value problems of mathematical physics $\left(1980^{\text {th }}\right.$ years);

- He has made a significant contribution to the development of non-Archimedean calculus, which is algebraically isomorphic to the classical calculus of Archimedes, and adapt it to the fundamental problems of modern astrophysics outer space $\left(1990^{\text {th }}\right.$ years $)$;

- Established an internationally recognized scientific school of Kharkiv for mathematical method of Rfunctions $\left(1970^{\text {th }}-2000^{\text {th }}\right.$ years $)$.

Here is the incomplete list of significant for the world of physics and mathematics community of scientific results academician of Ukrainian Academy of Sciences (NAS) Rvachev V.L. for many years of his active and fruitful work in the field of applied mathematics, classical mechanics, thermal physics, mathematical physics, cybernetics and electricity. Moreover, the results that can be proud of a real mathematician and who entered the treasury of the world of mathematics [3, 4, 39-43].

These results of research and teaching Rvachev V.L. We received recognition in the community and were awarded the following high state awards and marks of distinction $[4,39]$ :

- Order of the Red Banner of Labor (1961);

- election corresponding member of the Ukrainian Academy of Sciences (1972) and full member of the Ukrainian Academy of Sciences (1978);

- Order «Badge of Honor» (1976);

- award of the Prize of Academician A.N Dinnik of 
the Ukrainian Academy of Sciences (for outstanding contribution to the development of mathematical physics, 1976);

- awarding of the State Prize of Ukraine in Science and Technology (for the creation, development and practical application of the theory of R-functions, 1980);

- Order of Friendship of Peoples (1986) - rank of «Honored Worker of Science and Technology of Ukraine» (1997);

- Order of Prince Yaroslav the Wise V degree (2001);

- award of the title «Honorary Doctor» of the National Technical University «KhPI», Kharkiv National University of Radio Electronics and the University of Wisconsin (USA).

3. The scientific school of Kharkiv academic mathematician. The data presented in Section 2, it follows that the main scientific development scientist and mathematician Rvachev V.L. he created a mathematical theory R-functions with its numerous technical applications [3, 4, 42]. Due to the complex work carried out under the supervision of Academician V.L. Rvachev for a number of decades in IPMach of the Ukrainian Academy of Sciences (NASU), NTU «KhPI», KhIRE, KHAI and towards the development and practical application of the method of R-functions (RFM), it was formed by a recognized scientific school in the world [3, 4]. Below in Fig. 8-12 shows some of the scientists who formed the «backbone» of the scientific school. At the beginning of the 21 st century, this scientific school has 22 doctors of technical and physical and mathematical sciences and 70 candidates of physical and mathematical sciences [4, 42]. Among the talented scientists and students of Academician of the NASU V.L. Rvachev. There are two corresspondent members of the NASU - E. Alexander Evgenievich Bozhko and Yuri Grigorievich Stoyan working now in IPMach NASU [4, 41].

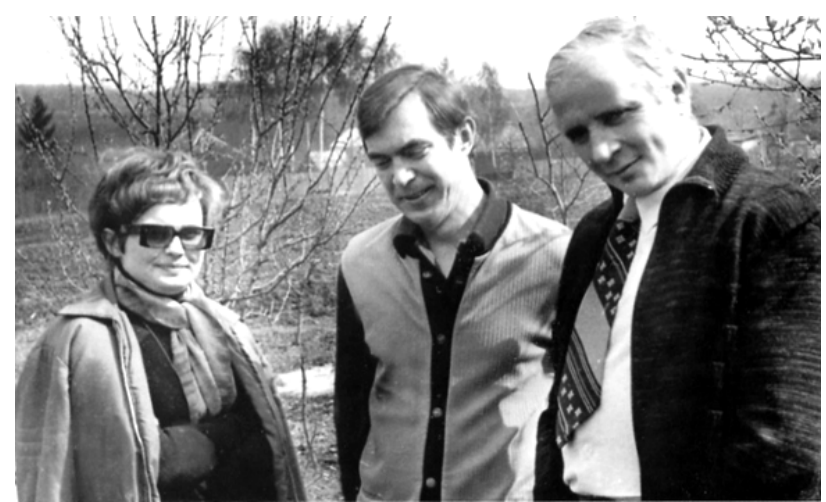

Fig. 8. Corresponding member of the UkrSSR Academy of Sciences Rvachev V.L. on vacation with his disciples IPMach of the Ukrainian Academy of Sciences and the future D.Sc. and the winners of the State Prize of Ukraine in the field of science and technology for 1980: Shejko T.I. (first left) and Slesarenko A.P. (center) (1972, a suburb of Kharkiv) [4]

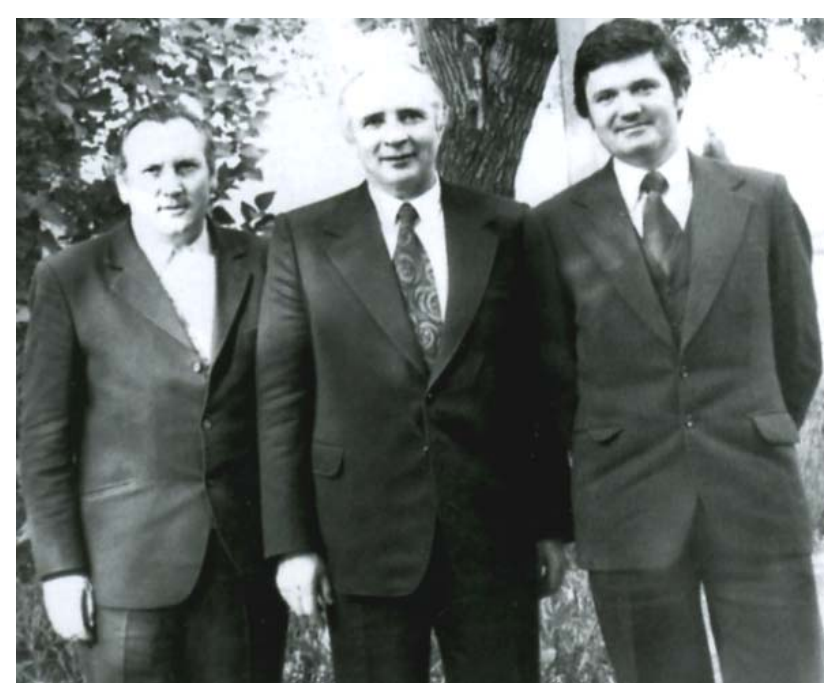

Fig. 9. Academician of the Ukrainian Academy of Sciences V.L. Rvachev (center) with his students, followers from IPMach of the Ukrainian Academy of Sciences: D.Sc. Goncharyuk I.V. (left) and future corresponding member of the NASU and the winner of the State Prize of Ukraine in the field of science and technology for 1980, D.Sc. Stoyan Yu.G. (right) (1978, IPMach of the Ukrainian Academy of Sciences, Kharkiv) [4]

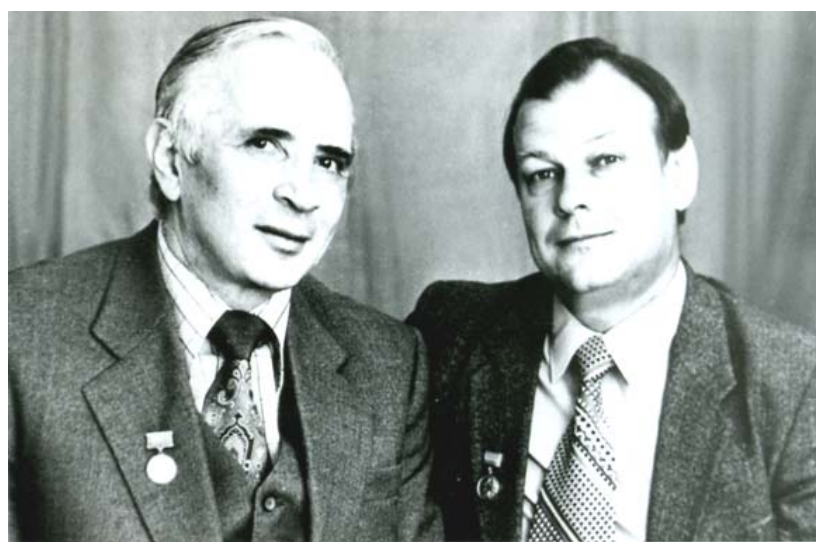

Fig. 10. Academician of the Ukrainian Academy of Sciences V.L. Rvachev (left) with his student D.Sc. winner of the State Prize of Ukraine in the field of science and technology for 1980 Protsenko V.S. (right) (1986, IPMach of the Ukrainian Academy of Sciences, Kharkiv) [4]

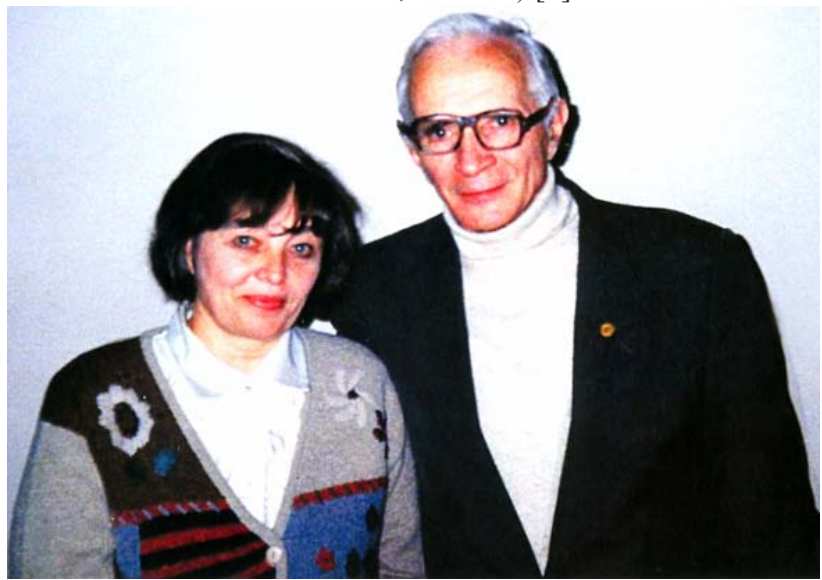

Fig. 11. Academician of the National Academy of Sciences of Ukraine Rvachev V.L. with his talented student, D. Sc. Prof. Kurpa Lydia Vasilievna - Head of the Department of Applied Mathematics at NTU «KhPI» (1999, NTU «KhPI», Kharkiv) [4] 


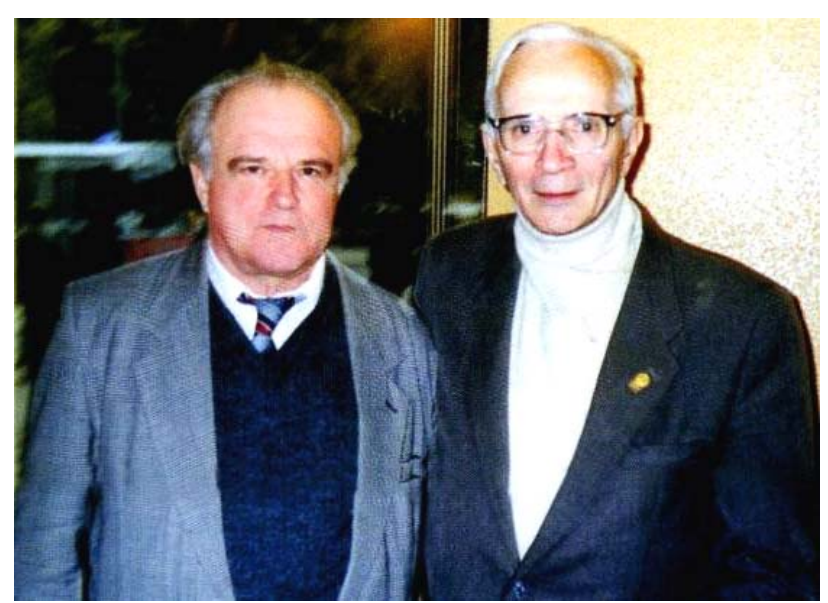

Fig. 12. Academician of the National Academy of Sciences of Ukraine V.L. Rvachev (right) and his student, D.Sc. Kravchenko V.F. (left) (1999, Kharkiv) [4]

One of his students, Prof. D.Sc. Lytvyn Oleg Nikolaevich won the prestigious awards named after Academician V.M. Glushkov and Academician M.V. Ostrogradskii of the NASU [41, 42]. Another of his disciple, D.Sc. Viktor Filippovich Kravchenko became honored worker of science and technology of the Russian Federation [43]. Section 1 has been given the names of six scientists and students from IPMach of the Ukrainian Academy of Sciences, which became in 1980 the winners of the State Prize of Ukraine in science and technology. Many of the students Rvachev V.L. or head of the department was headed by education in high schools of Kharkov and other cities of Ukraine (for example, B.N. Borisenko, V.P. Buzko, V.N. Verzhikovsky, I.V. Goncharyuk, V.D. Kozhukhov, L.V. Kurpa, L.N. Kutsenko, O.N. Litvin, V.S. Protsenko, N.S. Sinekop, I.B. Sirodzha, V.P. Fedko, Yu.P. Shabanov-Kushnarenko, T.I. Shejko, L.I. Shklyarov, A.V. Shmatko et al.) [4, 43].

4. Features of the personality and lifestyle of the Kharkiv academic mathematician. What was Vladimir Logvinovich outside his research interests and work? From the memoirs of his students to be their teacher, «was the epitome of Kindness and Love to the people» [42]. This smart, educated and talented man, a mathematician who became a world scale, organically embodied and connected scruples, compassion and the ability to assist the other person, the ability to enjoy other people's success and ability in science mentoring [4, 42]. They, has seen a lot in his life and in his youth passed through many sufferings and deprivations during the 1930s (because of the contrived political reasons for the arrest, conviction and subsequent to the end of his rehabilitation courageous parents), brought up a whole generation of scientists and mathematicians who called themselves «rvachevites» and proud of this title [4]. While on vacation, or at home, it is as a «workaholic», firmly adhered to the rules worked out over the years, «least one hour to devote scientific work at least one page a day to write about the results of the research» [4]. Mathematics was, as they say in «blood» family of Rvachev: his parents Logwin Fedorovich and Ksenia Alekseevna were school teacher of mathematics, Sister Catherine Logvinovna, having a hard way of life, it has become a well-known scientist-mathematician (one of the first in the USSR women-coder and corresponding member of the NASU) and wife Irina Konstantinova (Fig. 13), which became a 1952 teacher of mathematics in the higher school of the USSR and reliable support in the life of Vladimir Logvinovich [4, 41]. Together with her and her children - a son Valery and a daughter Irina they deserve «passed through life, enduring all the joys and sorrows» $[4,42]$.

In $[4,42]$ worthy and faithful disciple of Academician of the NASU V.L. Rvachev, Doctor of Technical Sciences, Prof., Head of the department of applied mathematics NTU «KhPI» Lidia Vasilievna Kurpa wrote about his teacher the following remarkable words: "... members of the Polytechnic University will always keep the memory of this talented Scientist, great Teachers and outstanding Person».

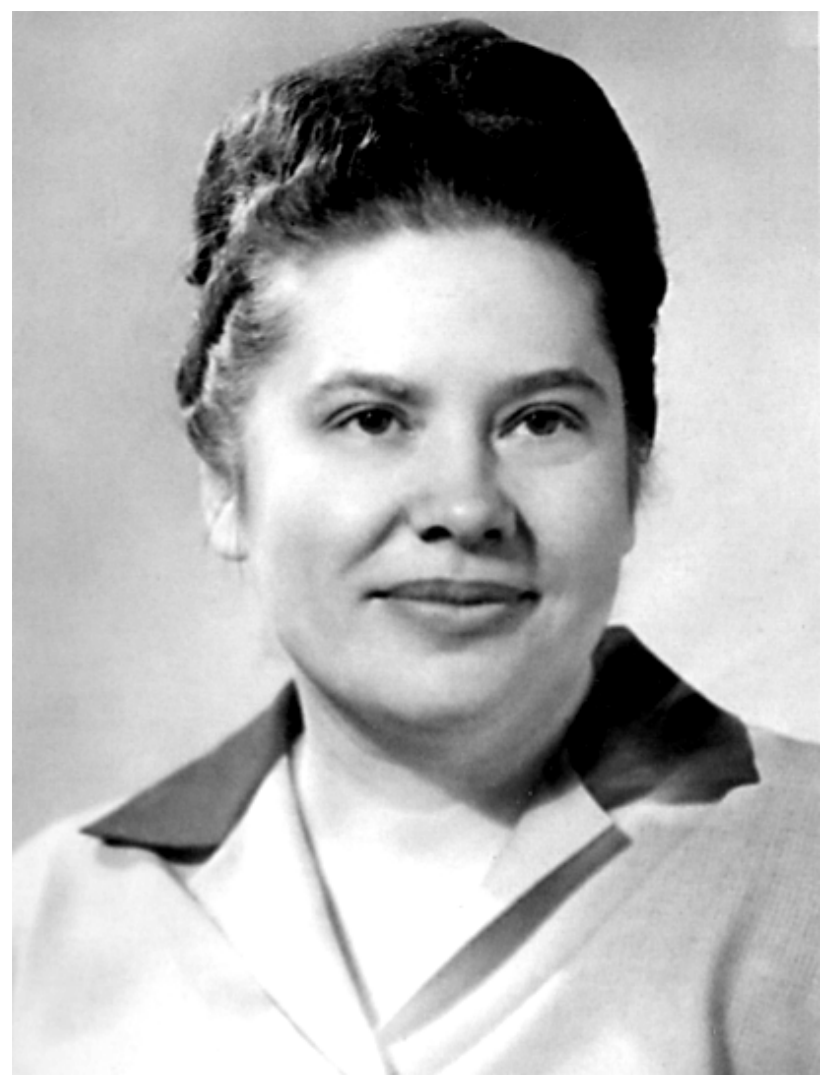

Fig. 13. Beloved wife and vital support of academician of the NASU Rvachev V.L., Math teacher at the Kharkiv Tank School (since March 2003 this institution was included as part of the faculty KhPI) Irina Konstantinova Rvacheva (Semiray) (1965, Kharkiv ) [4]

\section{REFERENCES}

1. Baranov M.I. an anthology of the distinguished achievements in science and technique. Part 26: Three portraits of worldwide known mathematicians of Kharkov region Elektro- 
tekhnika i elektromekhanika - Electrical engineering \& electromechanics, 2015, no.3, pp. 3-13. (Rus).

2. Baranov M.I. An anthology of the distinguished achievements in science and technique. Part 27: Portrait of the Kharkov mathematician Naum Il'ich Akhiezer. Elektrotekhnika $i$ elektromekhanika - Electrical engineering \& electromechanics, 2015, no.4, pp. 3-6. (Rus).

3. Gopko L.M., Kravchenko L.K., Shidlovskij A.K. Vladimir Logvinovich Rvachev. AN USSR (Biobibliografija uchenyh Ukr. $S S R$ ). [Vladimir Logvinovich Rvachev. Ukrainian Academy of Sciences (Biobibliography scientists Ukr. SSR)]. Kiev, Naukova dumka Publ., 1988. 52 p. (Rus)

4. Kurpa L.V., Shmatko T.V., Shmatko A.V. Rvachev Vladimir Logvinovich. Se chelovek. Mnogo zvanyh - Malo izbrannyh [Rvachev Vladimir Logvinovich. It homo. Many are called Not selected]. Kharkov, Novoe slovo Publ., 2006. 80 p. (Rus).

5. Rvachev V.L. The pressure on the elastic half-space stamp, in terms of having a band shape. Prikladnaja matematika i mekhanika - Applied Mathematics and Mechanics, 1956, vol.20, no.2, pp. 248-254. (Rus).

6. Mossakovskiy V.I., Rvachev V.L. On the problem of horizontal hydrodynamic shock sphere. Prikladnaja matematika $i$ mekhanika - Applied Mathematics and Mechanics, 1958, vol.22, no.6, pp. 847-849. (Rus).

7. Rvachev V.L. The character of the pressure distribution under the stamp, outlined in the plan two contiguous circles. Izvestija AN SSSR. Mekhanika i mashinostroenie - Proceedings of Academy of sciences of the USSR. Mechanics and machine construction, 1959, no.2, pp. 147-158. (Rus).

8. Rakov A.Kh., Rvachev V.L. Contact task theories of resiliency for half-space the module of resiliency of which is the sedate function of depth. Dopovidi AN Ukrainskoj SSR - Reports of Academy of sciences of the Ukrainian SSR, 1961, no.3, pp.286-290. (Ukr).

9. Bilik G.I., Rvachev V.L. About main integral equalization of contact task theories of resiliency for half-space the module of resiliency of which is the sedate function of depth. Dopovidi AN Ukrainskoj SSR - Reports of Academy of sciences of the Ukrainian SSR, 1962, no.8, pp. 1041-1044. (Ukr).

10. Rvachev V.L. An analytical description of some geometric objects. Doklady AN SSSR - Reports of Academy of sciences of the USSR, 1963, vol.153, no.4, pp. 765-768. (Rus).

11. Rvachev V.L. To the decision of one task of theory of potential. Dopovidi AN Ukrainskoj SSR - Reports of Academy of sciences of the Ukrainian SSR, 1958, no.2, pp. 144-146. (Ukr).

12. Rvachev V.L., Yushchenko E.L. Nekotorye voprosy analiticheskogo opisaniia geometricheskikh ob»ektov slozhnoi logicheskoi struktury [Some questions the analytical description of geometric objects with complex logic structure]. Kiev, Znanie USSR Publ., 1965. 53 p. (Rus).

13. Rvachev V.L., Stoyan Yu.G. On the optimal cutting material. Voprosy teoreticheskoj kibernetiki - Questions of theoretical cybernetics, 1965, pp. 189-199. (Rus).

14. Volkov A.P., Kravchenko V.F., Man'ko G.P., Rvachev V.L. On the solution of boundary task method by R- functions. Differencial'nye uravnenija - Differential equations, 1967, vol.3, no.9, pp. 1602-1605. (Rus).

15. Rvachev V.L., Shklyarov L.I. $\mathrm{R}_{\mathrm{x}}-$ functions. Dopovidi $A N$ Ukrainskoj SSR. Ser. A - Reports of Academy of sciences of the Ukrainian SSR. Ser. A, 1968, no.5, pp. 415-417. (Ukr).

16. Rvachev V.L., Uchishvili L.O. Calculation freely being plates by a method R- functions. Dopovidi AN Ukrainskoj SSR.
Ser. A - Reports of Academy of sciences of the Ukrainian SSR. Ser. A, 1968, no.10, pp. 935-937. (Ukr).

17. Rvachev V.L., Rakova L.V. Use of method for the decision of task on determination of frequencies and forms of vibrations of plates of difficult form. Dopovidi AN Ukrainskoj SSR. Ser. A - Reports of Academy of sciences of the Ukrainian SSR. Ser. A, 1969, no.10, pp. 902-905. (Ukr).

18. Kravchenko V.F., Polyakov V.F., Rvachev V.L. Solution of the task of diffraction of a plane wave by a system of two metal strips by a method R- functions. Radiotekhnika - Radio engineering, 1970, no.13, pp. 168-176. (Rus).

19. Rvachev V.L., Yarmolyuk V.K. About the use method Rfunctions for the decision of stationary tasks of heat conductivity and electrodynamics. Dopovidi AN Ukrainskoj SSR. Ser. A Reports of Academy of sciences of the Ukrainian SSR. Ser. A, 1971, no.11, pp. 1003-1005. (Ukr).

20. Rvachev V.L. Teorija $R$ - funkcij i nekotorye ee prilozhenija [Theory R- functions and some its applications]. Kiev, Naukova dumka Publ., 1982. 552 p. (Rus).

21. Rvachev V.L. Geometricheskie prilozhenija algebry logiki [Geometric algebra application logic]. Kiev, Naukova dumka Publ., 1967. 212 p. (Rus).

22. Rvachev V.L. Metody algebry logiki v matematicheskoj fizike [Methods of algebra of logic in mathematical physics]. Kiev, Naukova dumka Publ., 1974. 259 p. (Rus).

23. Bol'shoj illjustrirovannyj slovar' inostrannyh slov [Large illustrated dictionary of foreign words]. Moscow, Russkie slovari Publ., 2004. 957 p. (Rus).

24. Rvachev V.L., Slesarenko A.P. On a modification of the structural method for solving mixed boundary tasks of heat conduction for areas of complex shape. Matematicheskaja fizika Mathematical physics, 1974, no.15, pp. 137-140. (Rus).

25. Kravchenko V.F., Polevoy V.I., Rvachev V.L. The calculation of the basic parameters of antennas complex shapes by Rfunctions. Metrologicheskie voprosy radiofiziki - Metrological questions of radiophysics, 1974. pp.87-106. (Rus).

26. Rvachev V.L., Sheyko T.I. On the question of the distribution of the electric potential in the course of conducting liquid in a nonuniform magnetic field. Matematicheskaja fizika - Mathematical physics, 1975, no.18, pp. 135-139. (Rus).

27. Rvachev V.L., Slesarenko A.P. Algebra logiki i integral'nye preobrazovanija $v$ kraevyh zadachah [The algebra of logic and integral transformations in the boundary tasks]. Kiev, Naukova dumka Publ., 1976. 287 p. (Rus).

28. Rvachev V.L., Procenko V.S. Kontaktnye zadachi teorii uprugosti dlja neklassicheskih oblastej [The contact tasks theories of resiliency for non-classical areas]. Kiev, Naukova dumka Publ., 1977. 235 p. (Rus).

29. Rvachev V.L., Slesarenko A.P. Algebro-logicheskie i proekcionnye metody $v$ zadachah teploobmena [Algebraic, logical and projection methods in tasks of thermal exchange]. Kiev, Naukova dumka Publ., 1978. 140 p. (Rus).

30. Rvachev V.L., Rvachev V.A. Teorija priblizhenij $i$ atomarnye funkcii [Approximation theory and atomic functions]. Moscow, Znanie Publ., 1978. 64 p. (Rus).

31. Rvachev V.L., Rvachev V.A. Neklassicheskie metody teorii priblizhenij $v$ kraevyh zadachah [Non-classical methods of approximation theory to boundary tasks]. Kiev, Naukova dumka Publ., 1979. 196 p. (Rus).

32. Rvachev V.L., Sinekop N.S. Formula convolution method $\mathrm{R}$ - functions and their application to the construction of struc- 
tures of solutions of boundary tasks. Doklady AN SSSR - Reports of Academy of sciences of the USSR, 1980, vol.255, no.1, pp. 80-83. (Rus).

33. Rvachev V.L., Sinekop N.S. An approximate solution of the plane task theories of resiliency for orthotropic body R- functions method. Dopovidi AN Ukrainskoj SSR. Ser. A-Reports of Academy of sciences of the Ukrainian SSR. Ser. A, 1981, no.10, pp. 61-64. (Rus).

34. Rvachev V.L., Man'ko G.P. Avtomatizacija programmirovanija $v$ kraevyh zadachah [Automation programming in of boundary tasks]. Kiev, Naukova dumka Publ., 1983. 230 p. (Rus).

35. Rvachev V.L., Kurpa L.V., Shevchenko A.N. R- functions method in tasks of non-stationary vibrations of plates. Problemy prochnosti - Problems durability, 1984, no.6, pp. 22-25. (Rus).

36. Rvachev V.L., Kurpa L.V. Method R- functions in tasks of bending of anisotropic plates. Doklady AN SSSR - Reports of Academy of sciences of the USSR, 1985, vol.280, no.2, pp. 314317. (Rus).
37. Rvachev V.L., Kurpa L.V. $R-$ funkcii $v$ zadachah teorii plastin [R- functions in of tasks theory of plates]. Kiev, Naukova dumka Publ., 1987. 175 p. (Rus).

38. Rvachev V.L., Man'ko G.P. Theory R- functions in the mathematical modeling of physical fields. Elektronnoe modelirovanie-Electronic modeling, 1987, vol.9, no.2, pp. 3-6. (Rus). 39. Rvachev Vladimir Logvinovich (Rvachev Vladimir Logvinovich) Available at: https://ru.wikipedia.org/wiki/Рвачёв, Владимир Логвинович (accessed 28 February 2013). (Rus).

40. Available at: http://rvachev.narod.ru (accessed 08 October 2013). (Rus).

41. Available at: http://www.impach.kharkov.ua/ PersonPages/Rvachev.htm (accessed 20 August 2012). (Rus).

42. Available at: http://polytechnic.kpi.kharkov.ua/ ViewArticle.asp?id=1171 (accessed 12 March 2014). (Rus).

43. Available at: http://dic.academic.ru/dic.nsf/ruwiki/1289464 (accessed 11 May 2014). (Rus).

Received 03.07.2015

M.I. Baranov, Doctor of Technical Science, Chief Researcher, Scientific-\&-Research Planning-\&-Design Institute «Molniya» National Technical University «Kharkiv Polytechnic Institute», 47, Shevchenko Str., Kharkiv, 61013, Ukraine, phone+38057 7076841, e-mail: eft@kpi.kharkov.ua

\section{How to cite this article:}

Baranov M.I. An antology of the distinguished achievements in science and technique. Part 30: Portrait of the Kharkov mathematician, mechanical engineer and cyberneticist Vladimir Logvinovich Rvachev. Electrical engineering \& electromechanics, 2016, no.1, pp. 3-11. doi: 10.20998/2074-272X.2016.1.01. 